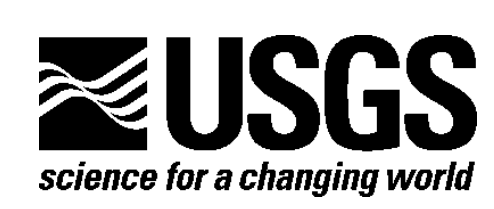

\title{
Digital Archive of Drilling Mud Weight Pressures and Wellbore Temperatures from 49 Regional Cross Sections of 967 Well Logs in Louisiana and Texas, Onshore Gulf of Mexico Basin
}

By Lauri A. Burke, Scott A. Kinney, and Temidayo B. Kola-Kehinde

Open-File Report 2011-1266 


\section{U.S. Department of the Interior \\ KEN SALAZAR, Secretary}

\section{U.S. Geological Survey \\ Marcia K. McNutt, Director}

U.S. Geological Survey, Reston, Virginia: 2011

For product and ordering information:

World Wide Web: http://www.usgs.gov/pubprod

Telephone: 1-888-ASK-USGS

For more information on the USGS-the Federal source for science about the Earth,

its natural and living resources, natural hazards, and the environment:

World Wide Web: http://www.usgs.gov

Telephone: 1-888-ASK-USGS

Suggested citation:

Burke, L.A., Kinney, S.A., and Kola-Kehinde, T.B., 2011, Digital archive of drilling mud weight pressures and wellbore temperatures from 49 regional cross sections of 967 well logs in Louisiana and Texas, onshore Gulf of Mexico basin: U.S. Geological Survey Open-File Report 2011-1266, 14 p.

Any use of trade, product, or firm names is for descriptive purposes only and does not imply endorsement by the U.S. Government.

Although this report is in the public domain, permission must be secured from the individual copyright owners to reproduce any copyrighted material contained within this report. 


\section{Contents}

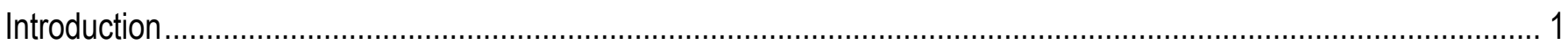

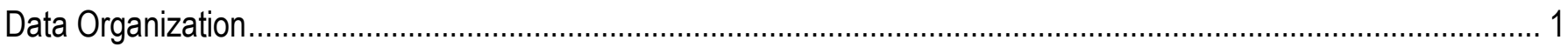

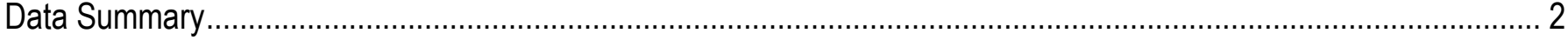

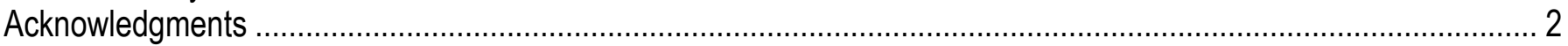

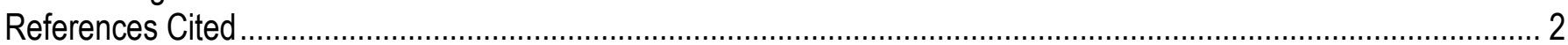

\section{Figures}

Figure 1. Map depicting the locations of the 20 regional cross sections spanning onshore Louisiana. Pressure, temperature, and depth data were acquired from subsurface geophysical logging headers from the 387 wells in these cross sections. Permission to show approximate well surface locations given by IHS Energy Group (K. Winner, IHS Energy Group, written commun., 2011) .............................................................. 4 Figure 2. Location map depicting the 29 regional strike and dip cross sections spanning onshore Texas. Pressure, temperature, and depth data were acquired from subsurface geophysical logging headers from the 580 wells in these cross sections. Permission to show approximate well surface locations given by IHS Energy Group (K. Winner, IHS Energy Group, written commun., 2011) ...

Figure 3. Temperature versus depth for the study wellbores located in Louisiana, onshore Gulf of Mexico basin

Figure 4. Drilling mud weight pressures versus depth for the study wellbores located in Louisiana, onshore

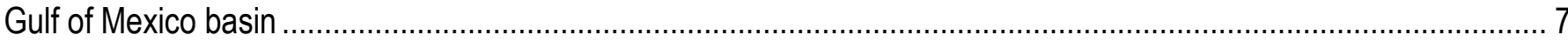

Figure 5. Temperature versus depth for the study wellbores located in Texas, onshore Gulf of Mexico basin ....... 8 Figure 6. Drilling mud weight pressures versus depth for the study wellbores located in Texas, onshore Gulf of Mexico basin.

\section{Tables}

Table 1. Summary of temperature and pressure data compiled for the digital archive of 967 wells from 49 regional cross sections that span the onshore portions of Texas and Louisiana, Gulf of Mexico basin.

Table 2. Temperature data from the wells in the onshore Louisiana region. The minimum, arithmetic average, and maximum temperatures are given in degrees Fahrenheit $\left({ }^{\circ} \mathrm{F}\right)$ for each 1,000 -foot $(\mathrm{ft})$ depth increment......

Table 3. Temperature data from the wells in the onshore Texas region. The minimum, arithmetic average, and maximum temperatures are given in degrees Fahrenheit $\left({ }^{\circ} \mathrm{F}\right)$ for each 1,000 -foot $(\mathrm{ft})$ depth increment

Table 4. Drilling mud weight pressures from the wells in the onshore Louisiana region. The minimum, arithmetic average, and maximum pressures are given in pounds per gallon (ppg) for each 1,000-foot (ft) depth increment.

Table 5. Drilling mud weight pressure data from the wells in the onshore Texas region. The minimum, arithmetic average, and maximum pressures are given in pounds per gallon (ppg) for each 1,000-foot (ft) depth increment. 


\section{Conversion Factors}

Inch/Pound to SI

\begin{tabular}{lcl}
\hline Multiply & \multicolumn{1}{c}{ By } & \multicolumn{1}{c}{ To obtain } \\
\hline foot $(\mathrm{ft})$ & Length & \\
\hline & 0.3048 & meter $(\mathrm{m})$ \\
\hline pound per gallon (ppg) & Density & \\
\hline
\end{tabular}

Temperature in degrees Fahrenheit $\left({ }^{\circ} \mathrm{F}\right)$ may be converted to degrees Celsius $\left({ }^{\circ} \mathrm{C}\right)$ as follows:

${ }^{\circ} \mathrm{C}=\left({ }^{\circ} \mathrm{F}-32\right) / 1.8$ 


\title{
Digital Archive of Drilling Mud Weight Pressures and Wellbore Temperatures from 49 Regional Cross Sections of 967 Well Logs in Louisiana and Texas, Onshore Gulf of Mexico Basin
}

By Lauri A. Burke, Scott A. Kinney, and Temidayo B. Kola-Kehinde

\begin{abstract}
This document provides the digital archive of in-situ temperature and drilling mud weight pressure data that were compiled from several historical sources. The data coverage includes the states of Texas and Louisiana in the Gulf of Mexico basin. Data are also provided graphically, for both Texas and Louisiana, as plots of temperature as a function of depth and pressure as a function of depth. The minimum, arithmetic average, and maximum values are tabulated for each 1,000-foot depth increment for temperature as well as pressure in the Texas and Louisiana data.
\end{abstract}

\section{Introduction}

The digital archive of data given in this publication is a compilation of wellbore temperature and pressure data for oil and gas wells drilled in the onshore portions of Texas and Louisiana, Gulf of Mexico basin. The data were derived from several paper-based sources (Bebout and Gutiérrez, 1982; 1983; Dodge and Posey, 1981; Eversull, 1984; Foote and others, 1990), and are compiled in this report to provide the information in an organized, digital format. For the onshore portions of the states of Texas and Louisiana, table 1 provides a summary of the number of cross sections, wells, temperature data points, and pressure data points included in this publication. As such, the two digital files provide 2,765 in-situ temperature measurements and 3,369 pressure measurements spanning an extensive range of depths across the Gulf Coast states of Texas and Louisiana.

The approximate surface locations of these oil and gas wells from Louisiana are illustrated in figure 1. Figure 2 shows the approximate surface locations of the Texas wells. Note that these well surface locations are for display purposes only and have been modified by a randomized algorithm in order to maintain the proprietary nature of the actual well surface locations.

\section{Data Organization}

This document and the associated digital files serve as a digital archive of the data used in the U.S. Geological Survey investigation of temperature and overpressure relations in the Gulf of Mexico basin. These digital files were constructed from information located in the geophysical well logging header files for wells drilled in the onshore portions of Texas and Louisiana. The standardized American Petroleum Institute (API) well numbers or the unique well identification (UWI) numbers are decoupled from these data sets in order to preserve the ambiguity of the well operators and the exact surface 
locations of the wells. Consequently, the data for the well information in these files are systematically labeled based on (1) the regional cross section letter (or number for the along-strike cross sections in Texas) and (2) the sequential well location within the cross section. For example, the second well in the Louisiana $\mathrm{J}$ to $\mathrm{J}$ ' regional cross section is labeled with cross section $\mathrm{J}-\mathrm{J}$ ' and study well number 2; the third well in the 1 to 1 ' strike cross section spanning Texas is labeled with cross section 1-1' and study well number 3.

The temperature and pressure data for Texas and Louisiana are provided in the two files, TX_Temp_Pressure.xls and LA_Temp_Pressure.xls, respectively. These files are provided in digital Microsoft Excel format. The Texas data, $T X_{-}$Temp_Pressure.xls, are tabulated into eight columns of information that provide (1) the regional cross section label, (2) the study well number, (3) Texas land survey name, (4) Texas land survey section number, (5) temperature, (6) depth, (7) pressure measurements, and (8) the source of the original data for a given wellbore. The Louisiana data, LA_Temp_Pressure.xls, are tabulated into nine columns of information that provide (1) the regional cross section letter, (2) the study well number, (3) section, (4) township, (5) range, (6) temperature, (7) depth, (8) pressure measurement, and (9) the original source of the data for a given wellbore.

Temperatures, in degrees Fahrenheit $\left({ }^{\circ} \mathrm{F}\right)$, presented in this report, represent the raw temperature measurements as given in the well log header files. Pressure measurements, in pounds per gallon (ppg), are from the drilling mud weights provided in the well log header files. Depth measurements, in feet (ft), represent the driller depth measurements, or in some cases, the bottom of the logged interval. Due to the historical nature of the paper-based data sources, the depth measurements were manually determined based on the printed depth scales available in the margins of the cross section folios. As such, these databases represent a unique data contribution.

\section{Data Summary}

In addition to these digital files, the temperature and pressure data are also shown graphically. Figure 3 illustrates the subsurface temperature characteristics of Louisiana, in which the temperature data are plotted against depth; figure 4 illustrates the pressure characteristics of Louisiana, in which the drilling mud weight pressures are graphed against depth. Figure 5 illustrates the temperature distribution as a function of depth for Texas; figure 6 illustrates the pressure distribution as a function of depth for Texas. Tables 2 and 3 show the number of data points, as well as the minimum, arithmetic average, and maximum temperatures by 1,000-ft depth increments, for the states of Louisiana and Texas, respectively. Tables 4 and 5 provide the number of data points, as well as the minimum, arithmetic average, and maximum drilling mud weight pressures by 1,000-ft depth increments for the states of Louisiana and Texas, respectively.

\section{Acknowledgments}

Reviews by U.S. Geological Survey research geologists K. Lewis and J. Eoff resulted in improvements to the manuscript. Permission to show approximate well surface locations was given by IHS Energy Group (K. Winner, IHS Energy Group, written commun., 2011).

\section{References Cited}

Bebout, D.G., and Gutiérrez, D.R., 1982, Regional cross sections, Louisiana Gulf Coast, western part:

Baton Rouge, Louisiana, Louisiana Geological Survey Folio Series No. 5, 11 panels.

Bebout, D.G., and Gutiérrez, D.R., 1983, Regional cross sections, Louisiana Gulf Coast, eastern part:

Baton Rouge, Louisiana, Louisiana Geological Survey Folio Series No. 6, 10 panels. 
Dodge, M.M., and Posey, J.S., 1981, Structural cross sections, Tertiary formations, Texas Gulf Coast: Austin, The University of Texas at Austin, Bureau of Economic Geology Cross Section Series No. 2, 33 plates, $6 \mathrm{p}$.

Eversull, L.G., 1984, Regional cross sections, Northern Louisiana: Baton Rouge, Louisiana, Louisiana Geological Survey Folio Series No. 7, 11 panels.

Foote, R.Q., Stoudt, D.L., McCulloh, R.P., and Eversull, L.G., 1990, Gulf Coast regional cross section-Southwest Arkansas-northwest Louisiana sector: Tulsa, Oklahoma, American Association of Petroleum Geologists, 3 sheets.

Publishing support provided by:

Denver Publishing Service Center

For more information concerning this publication, contact:

Center Director, USGS Central Energy Resources Science Center

Box 25046, Mail Stop 939

Denver, CO 80225

(303) 236-1647

Or visit the Central Energy Resources Science Center Web site at: http://energy.cr.usgs.gov/ 


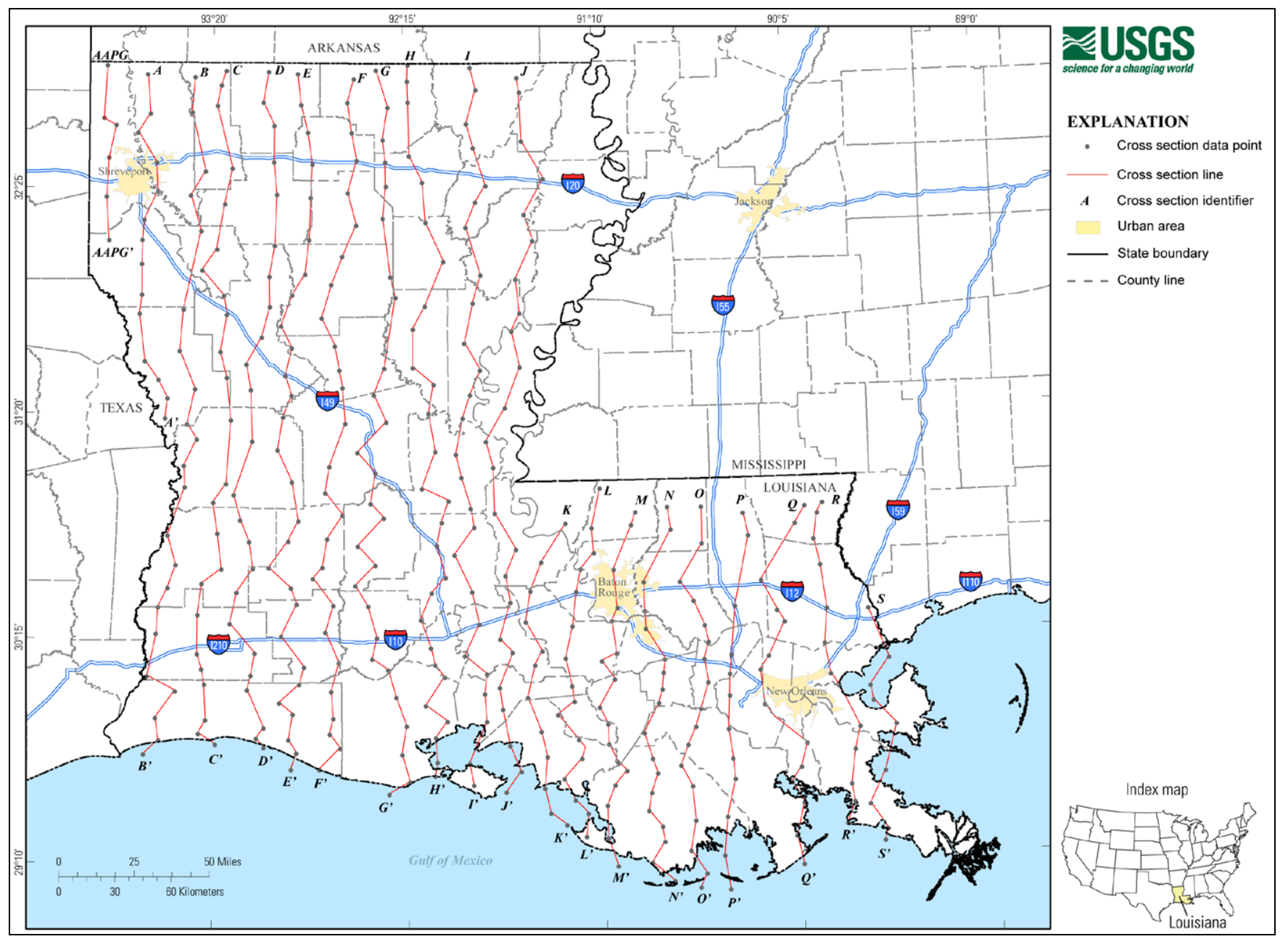

Figure 1. Map depicting the locations of the 20 regional cross sections spanning onshore Louisiana. Pressure, temperature, and depth data were acquired from subsurface geophysical log headers from the 387 wells in these cross sections. The data source for the AAPG-AAPG' cross section is Foote and others (1990). The data sources for the A-A' through S-S' cross sections are Bebout and Gutiérrez $(1982,1983)$ and Eversull (1984). Permission to show approximate well surface locations given by IHS Energy Group (K. Winner, IHS Energy Group, written commun., 2011). 


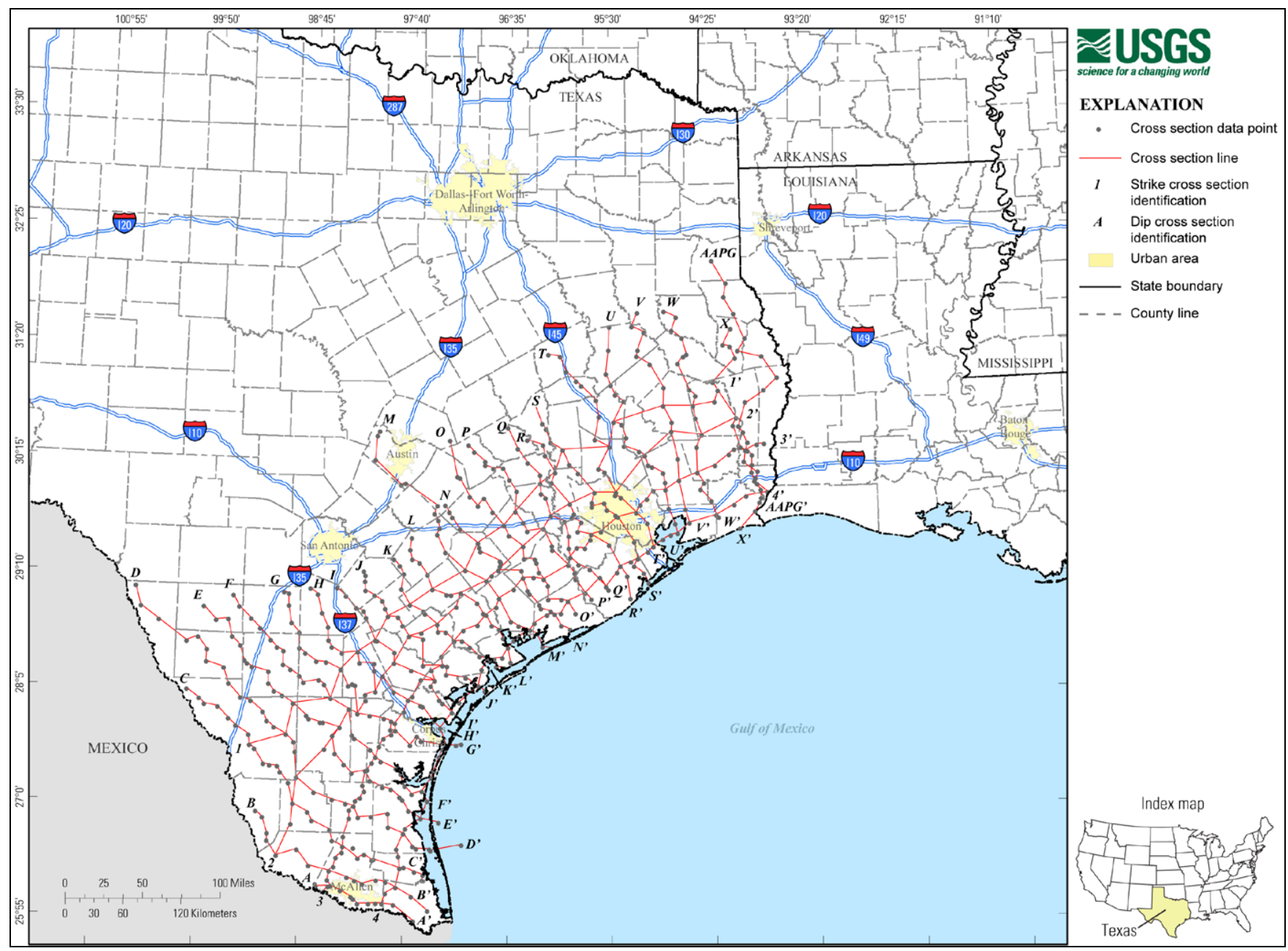

Figure 2. Map depicting the 29 regional strike and dip cross sections spanning onshore Texas. Pressure, temperature, and depth data were acquired from subsurface geophysical logging headers from the 580 wells in these cross sections. The data source for the AAPG-AAPG' cross section is Foote and others (1990). The data sources for the A-A' through X-X' and the 1-1' through 4-4' cross sections are Dodge and Posey (1981). Permission to show approximate well surface locations given by IHS Energy Group (K. Winner, IHS Energy Group, written commun., 2011). 


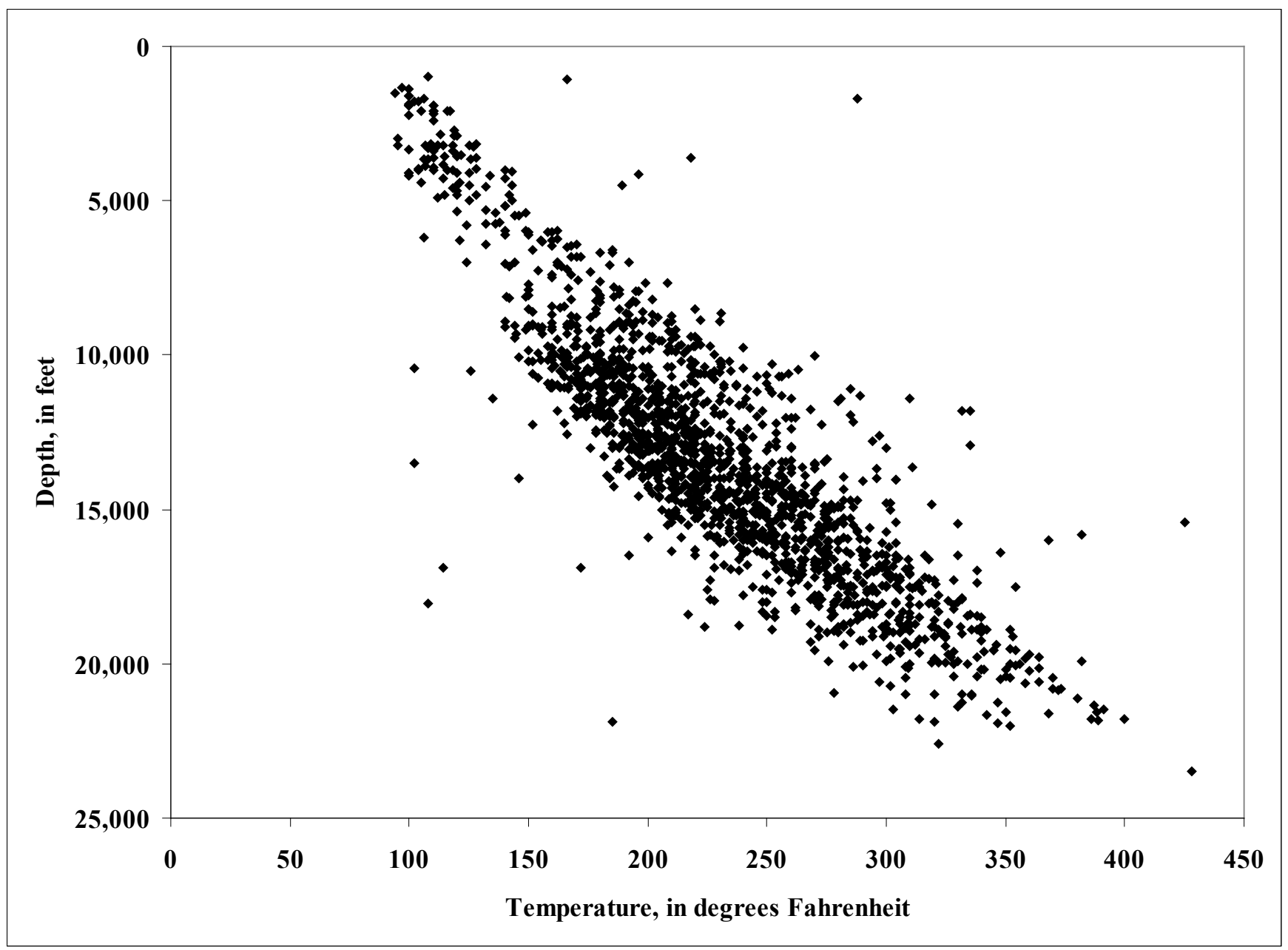

Figure 3. Temperature versus depth for the study wellbores located in Louisiana, onshore Gulf of Mexico basin. 


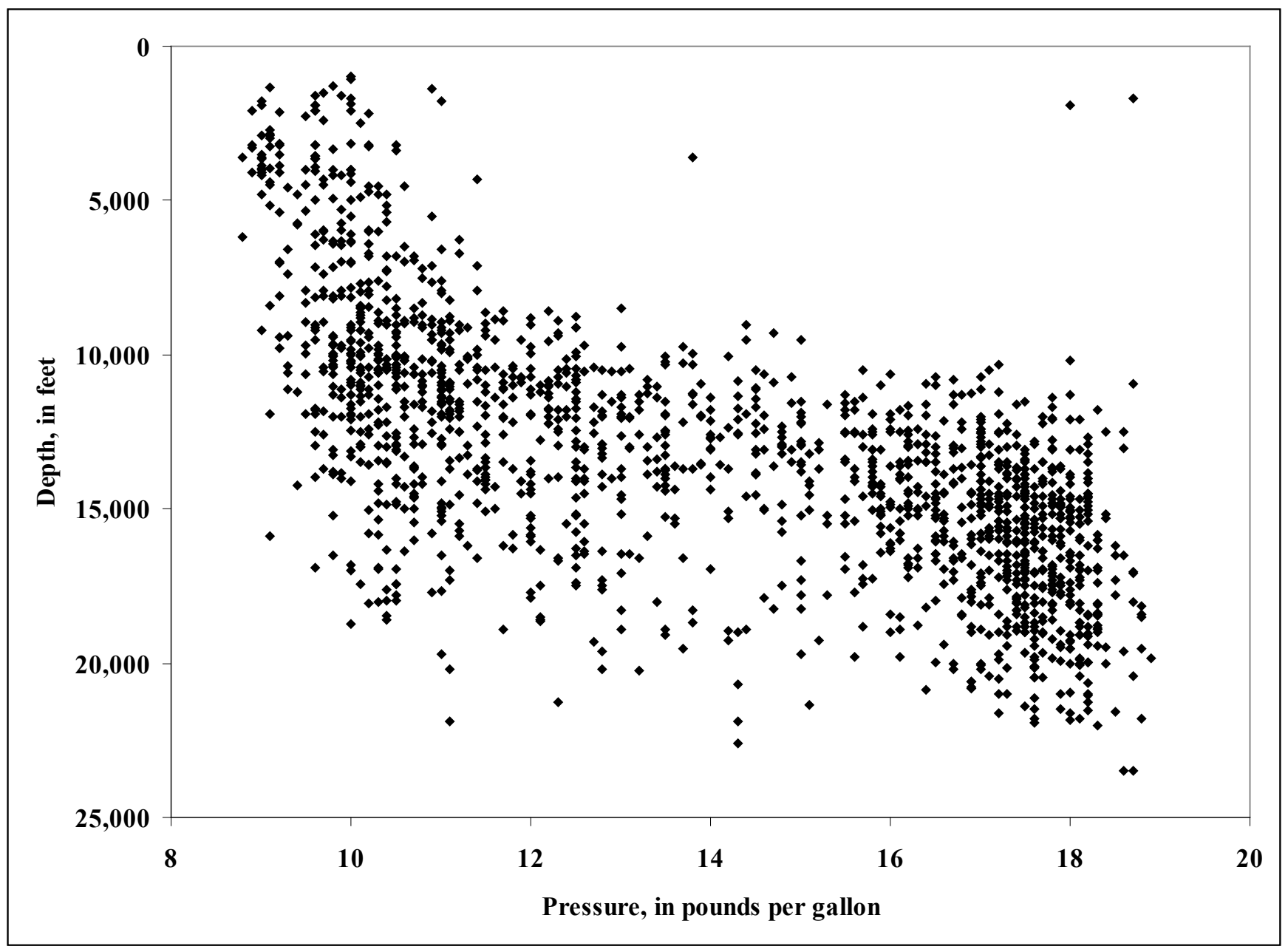

Figure 4. Drilling mud weight pressures versus depth for the study wellbores located in Louisiana, onshore Gulf of Mexico basin. 


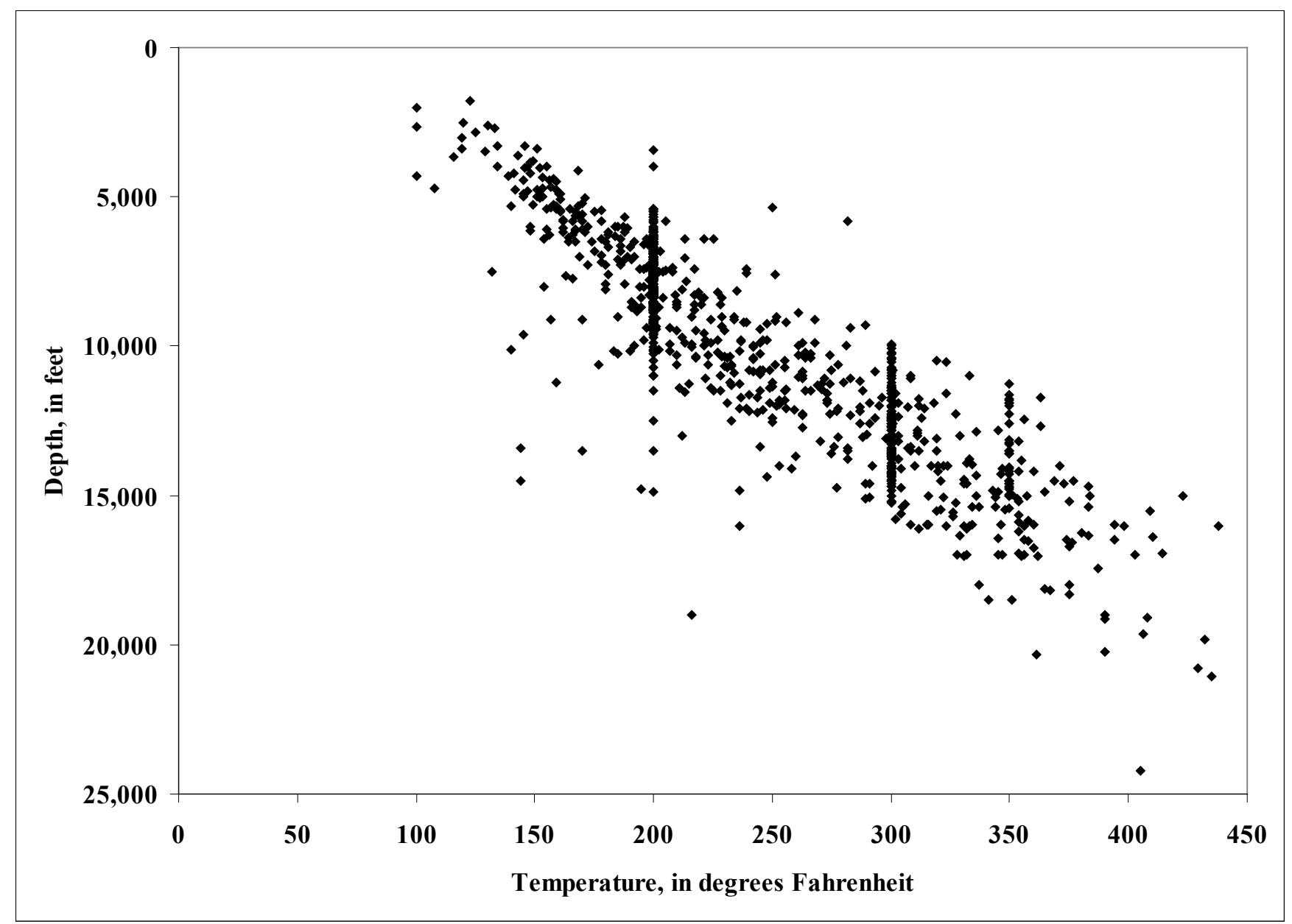

Figure 5. Temperature versus depth for the study wellbores located in Texas, onshore Gulf of Mexico basin. 


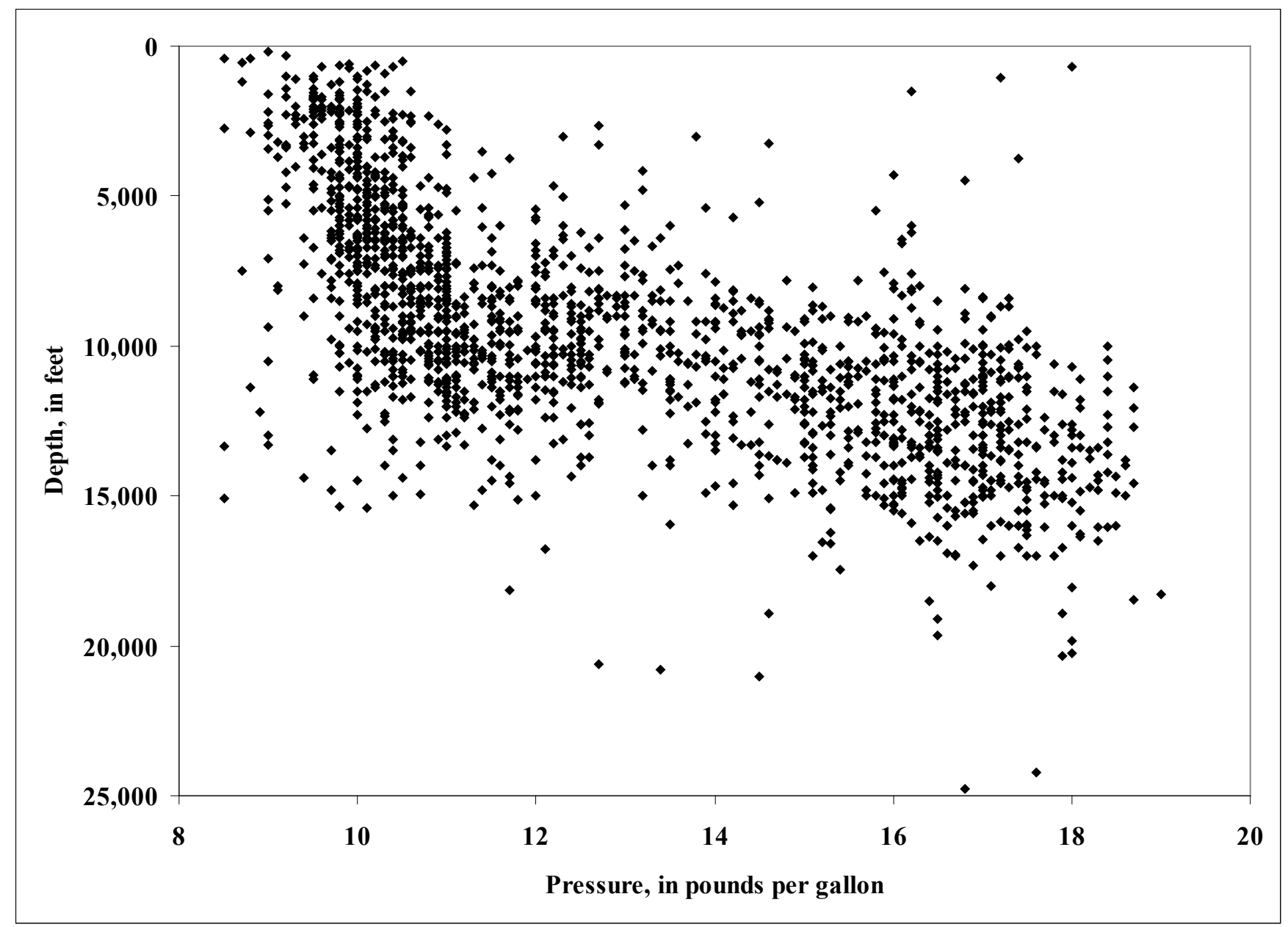

Figure 6. Drilling mud weight pressures versus depth for the study wellbores located in Texas, onshore Gulf of Mexico basin. 
Table 1. Summary of temperature and pressure data compiled for the digital archive of 967 wells from 49 regional cross sections that span the onshore portions of Texas and Louisiana, Gulf of Mexico basin.

\begin{tabular}{rcccc}
\hline \multicolumn{1}{l}{ Location } & $\begin{array}{c}\text { Number of } \\
\text { cross sections }\end{array}$ & $\begin{array}{c}\text { Number of } \\
\text { wells }\end{array}$ & $\begin{array}{c}\text { Temperature } \\
\text { data points }\end{array}$ & $\begin{array}{c}\text { Pressure } \\
\text { data points }\end{array}$ \\
\hline Louisiana & 20 & & & \\
Texas & 29 & 387 & 1,705 & 1,692 \\
Totals & 49 & 580 & 1,060 & 1,677 \\
\end{tabular}


Table 2. Temperature data from the wells in the onshore Louisiana region. The minimum, arithmetic average, and maximum temperatures are given in degrees Fahrenheit $\left({ }^{\circ} \mathrm{F}\right)$ for each 1,000-foot (ft) depth increment.

\begin{tabular}{|c|c|c|c|c|}
\hline $\begin{array}{l}\text { Depth interval } \\
(\mathrm{ft})\end{array}$ & $\begin{array}{c}\text { Minimum } \\
\text { temperature } \\
\left({ }^{\circ} \mathrm{F}\right)\end{array}$ & $\begin{array}{c}\text { Average } \\
\text { temperature } \\
\left({ }^{\circ} \mathrm{F}\right)\end{array}$ & $\begin{array}{l}\text { Maximum } \\
\text { temperature } \\
\left({ }^{\circ} \mathrm{F}\right)\end{array}$ & Data points \\
\hline $0-1,000$ & - & - & - & - \\
\hline $1,000-2,000$ & 94 & 118 & 288 & 16 \\
\hline $2,000-3,000$ & 100 & 112 & 120 & 12 \\
\hline $3,000-4,000$ & 95 & 117 & 218 & 31 \\
\hline $4,000-5,000$ & 100 & 126 & 196 & 29 \\
\hline $5,000-6,000$ & 120 & 139 & 162 & 17 \\
\hline $6,000-7,000$ & 106 & 158 & 185 & 24 \\
\hline $7,000-8,000$ & 124 & 167 & 199 & 28 \\
\hline $8,000-9,000$ & 140 & 183 & 231 & 50 \\
\hline $9,000-10,000$ & 140 & 184 & 240 & 87 \\
\hline $10,000-11,000$ & 102 & 192 & 270 & 146 \\
\hline $11,000-12,000$ & 135 & 202 & 335 & 170 \\
\hline $12,000-13,000$ & 152 & 212 & 335 & 159 \\
\hline $13,000-14,000$ & 102 & 222 & 311 & 174 \\
\hline $14,000-15,000$ & 184 & 241 & 319 & 181 \\
\hline $15,000-16,000$ & 200 & 252 & 425 & 151 \\
\hline $16,000-17,000$ & 114 & 268 & 368 & 124 \\
\hline $17,000-18,000$ & 225 & 286 & 354 & 101 \\
\hline $18,000-19,000$ & 108 & 295 & 352 & 93 \\
\hline $19,000-20,000$ & 268 & 318 & 382 & 55 \\
\hline $20,000-21,000$ & 278 & 337 & 373 & 31 \\
\hline $21,000-22,000$ & 185 & 343 & 400 & 23 \\
\hline $22,000-23,000$ & 322 & 337 & 352 & 2 \\
\hline $23,000-24,000$ & 428 & 428 & 428 & 1 \\
\hline Overall & 94 & 229 & 428 & 1,705 \\
\hline
\end{tabular}

Table 3. Temperature data from the wells in the onshore Texas region. The minimum, arithmetic average, and maximum temperatures are given in degrees Fahrenheit $\left({ }^{\circ} \mathrm{F}\right)$ for each 1,000-foot (ft) depth increment. 


\begin{tabular}{|c|c|c|c|c|}
\hline $\begin{array}{l}\text { Depth Interval } \\
\text { (ft) }\end{array}$ & $\begin{array}{c}\text { Minimum } \\
\text { temperature } \\
\left({ }^{\circ} \mathrm{F}\right)\end{array}$ & $\begin{array}{c}\text { Average } \\
\text { temperature } \\
\left({ }^{\circ} \mathrm{F}\right)\end{array}$ & $\begin{array}{c}\text { Maximum } \\
\text { temperature } \\
\left({ }^{\circ} \mathrm{F}\right)\end{array}$ & Data points \\
\hline $0-1,000$ & - & - & - & - \\
\hline $1,000-2,000$ & 123 & 123 & 123 & 1 \\
\hline $2,000-3,000$ & 100 & 118 & 133 & 6 \\
\hline $3,000-4,000$ & 116 & 141 & 200 & 11 \\
\hline $4,000-5,000$ & 100 & 149 & 200 & 27 \\
\hline $5,000-6,000$ & 140 & 178 & 282 & 44 \\
\hline $6,000-7,000$ & 148 & 191 & 225 & 99 \\
\hline $7,000-8,000$ & 132 & 199 & 251 & 166 \\
\hline $8,000-9,000$ & 154 & 202 & 261 & 140 \\
\hline $9,000-10,000$ & 145 & 216 & 300 & 79 \\
\hline $10,000-11,000$ & 138 & 250 & 323 & 74 \\
\hline $11,000-12,000$ & 159 & 277 & 363 & 88 \\
\hline $12,000-13,000$ & 200 & 295 & 363 & 82 \\
\hline $13,000-14,000$ & 200 & 306 & 355 & 73 \\
\hline $14,000-15,000$ & 144 & 316 & 383 & 73 \\
\hline $15,000-16,000$ & 289 & 339 & 452 & 39 \\
\hline $16,000-17,000$ & 236 & 356 & 438 & 30 \\
\hline $17,000-18,000$ & 331 & 352 & 387 & 8 \\
\hline $18,000-19,000$ & 337 & 359 & 375 & 7 \\
\hline $19,000-20,000$ & 216 & 374 & 432 & 6 \\
\hline $20,000-21,000$ & 361 & 411 & 463 & 4 \\
\hline $21,000-22,000$ & 435 & 435 & 435 & 1 \\
\hline $22,000-23,000$ & - & - & - & - \\
\hline $23,000-24,000$ & - & - & - & - \\
\hline $24,000-25,000$ & 405 & 453 & 500 & 2 \\
\hline Overall & 100 & 244 & 500 & 1,060 \\
\hline
\end{tabular}


Table 4. Drilling mud weight pressures from the wells in the onshore Louisiana region. The minimum, arithmetic average, and maximum pressures are given in pounds per gallon (ppg) for each 1,000-foot (ft) depth increment.

\begin{tabular}{|c|c|c|c|c|}
\hline $\begin{array}{l}\text { Depth Interval } \\
\text { (ft) }\end{array}$ & $\begin{array}{l}\text { Minimum } \\
\text { Pressure } \\
\text { (ppg) }\end{array}$ & $\begin{array}{c}\text { Average } \\
\text { Pressure } \\
\text { (ppg) }\end{array}$ & $\begin{array}{l}\text { Maximum } \\
\text { Pressure } \\
\text { (ppg) }\end{array}$ & Data Points \\
\hline $0-1,000$ & - & - & - & - \\
\hline $1,000-2,000$ & 9.0 & 10.8 & 18.7 & 17 \\
\hline $2,000-3,000$ & 8.9 & 9.5 & 10.2 & 13 \\
\hline $3,000-4,000$ & 8.8 & 9.6 & 13.8 & 30 \\
\hline $4,000-5,000$ & 8.9 & 9.7 & 11.4 & 32 \\
\hline $5,000-6,000$ & 9.1 & 9.9 & 10.9 & 17 \\
\hline $6,000-7,000$ & 8.8 & 10.1 & 11.2 & 27 \\
\hline $7,000-8,000$ & 9.2 & 10.2 & 11.4 & 28 \\
\hline $8,000-9,000$ & 9.1 & 10.6 & 13.0 & 49 \\
\hline $9,000-10,000$ & 9.0 & 10.9 & 15.0 & 86 \\
\hline $10,000-11,000$ & 9.3 & 11.6 & 18.7 & 145 \\
\hline $11,000-12,000$ & 9.1 & 12.6 & 18.3 & 163 \\
\hline $12,000-13,000$ & 9.6 & 13.9 & 18.6 & 158 \\
\hline $13,000-14,000$ & 9.6 & 14.5 & 18.6 & 176 \\
\hline $14,000-15,000$ & 9.4 & 15.3 & 18.2 & 179 \\
\hline $15,000-16,000$ & 9.1 & 15.7 & 18.4 & 149 \\
\hline $16,000-17,000$ & 9.6 & 15.9 & 18.6 & 121 \\
\hline $17,000-18,000$ & 10.0 & 16.1 & 18.7 & 100 \\
\hline $18,000-19,000$ & 10.0 & 16.5 & 18.8 & 91 \\
\hline $19,000-20,000$ & 11.0 & 17.0 & 18.9 & 53 \\
\hline $20,000-21,000$ & 11.1 & 16.9 & 18.7 & 31 \\
\hline $21,000-22,000$ & 11.1 & 17.1 & 18.8 & 23 \\
\hline $22,000-23,000$ & 14.3 & 16.3 & 18.3 & 2 \\
\hline $23,000-24,000$ & 18.6 & 18.7 & 18.7 & 2 \\
\hline Overall & 8.8 & 13.9 & 18.9 & 1,692 \\
\hline
\end{tabular}


Table 5. Drilling mud weight pressure data from the wells in the onshore Texas region. The minimum, arithmetic average, and maximum pressures are given in pounds per gallon (ppg) for each 1,000-foot (ft) depth increment.

\begin{tabular}{|c|c|c|c|c|}
\hline $\begin{array}{l}\text { Depth Interval } \\
\text { (ft) }\end{array}$ & $\begin{array}{c}\text { Minimum } \\
\text { Pressure } \\
\text { (ppg) }\end{array}$ & $\begin{array}{c}\text { Average } \\
\text { Pressure } \\
\text { (ppg) }\end{array}$ & $\begin{array}{c}\text { Maximum } \\
\text { Pressure } \\
\text { (ppg) }\end{array}$ & Data Points \\
\hline $0-1,000$ & 8.5 & 9.4 & 9.9 & 5 \\
\hline $1,000-2,000$ & 8.7 & 10.1 & 17.2 & 35 \\
\hline $2,000-3,000$ & 8.5 & 9.8 & 11.0 & 61 \\
\hline $3,000-4,000$ & 8.5 & 9.9 & 11.0 & 47 \\
\hline $4,000-5,000$ & 9.2 & 10.2 & 16.0 & 55 \\
\hline $5,000-6,000$ & 9.0 & 10.4 & 14.2 & 72 \\
\hline $6,000-7,000$ & 9.4 & 10.8 & 16.2 & 102 \\
\hline $7,000-8,000$ & 8.7 & 11.2 & 16.2 & 106 \\
\hline $8,000-9,000$ & 9.1 & 11.9 & 17.3 & 161 \\
\hline $9,000-10,000$ & 9.0 & 12.4 & 17.5 & 178 \\
\hline $10,000-11,000$ & 9.0 & 13.2 & 18.4 & 215 \\
\hline $11,000-12,000$ & 8.8 & 13.8 & 18.7 & 206 \\
\hline $12,000-13,000$ & 8.9 & 14.9 & 18.7 & 115 \\
\hline $13,000-14,000$ & 8.5 & 15.4 & 18.6 & 111 \\
\hline $14,000-15,000$ & 9.7 & 15.9 & 18.7 & 97 \\
\hline $15,000-16,000$ & 8.5 & 15.8 & 18.6 & 54 \\
\hline $16,000-17,000$ & 12.1 & 17.0 & 18.5 & 30 \\
\hline $17,000-18,000$ & 7.2 & 15.7 & 17.8 & 9 \\
\hline $18,000-19,000$ & 11.7 & 17.0 & 19.0 & 7 \\
\hline $19,000-20,000$ & 16.5 & 17.0 & 18.0 & 3 \\
\hline $20,000-21,000$ & 12.7 & 15.5 & 18.0 & 4 \\
\hline $21,000-22,000$ & 14.5 & 14.5 & 14.5 & 1 \\
\hline $22,000-23,000$ & - & - & - & - \\
\hline $23,000-24,000$ & - & - & - & - \\
\hline $24,000-25,000$ & 16.8 & 17.2 & 17.6 & 3 \\
\hline Overall & 5.5 & 12.9 & 19.0 & 1,677 \\
\hline
\end{tabular}

